\title{
Empirical Analysis of the External Determinants of the Budget Deficit:Case of Morocco
}

\author{
Mohamed LAKHDAR ${ }^{1}$, Aziz BENSBAHOU ${ }^{2}$ \\ ${ }^{1} \mathrm{Ph}$. D Scholar in Economics \\ ${ }^{2}$ Researcher professor \\ Faculty of Law, Economics and Social Sciences. Kenitra \\ Ibn Toufail University-Kenitra, Morocco
}

\begin{abstract}
This work aims to examine the effect of external variables on the budget balance in Morocco using annual data for the period (1980-2016). The empirical results of the estimation of the VAR model show that the external variables have direct and indirect effects on the budget balance. A positive oil price shock does not have a significant influence on the budget balance in the short term. But, its indirect long-term effect is significant. Furthermore, a positive shock to the real effective exchange rate generates a widening budget deficit. The degree of trade openness has a positive effect on the fiscal balance in the short and long term.
\end{abstract}

Keywords:Budget Balance; Commercial Opening; Real Effective Exchange Rate; Oil Price; VAR Model.

\section{INTRODUCTION}

The various macroeconomic imbalances are at the center of the concerns and research of many economists and institutions such as the IMF. These imbalances concern the current account deficit or surplus, the budget deficit, public debt, external debt, savings, investment, as well as high rates of accumulation of foreign reserves.

Baracke and al (2008) define macroeconomic imbalances as the external positions of economies systematically large, which present disruptions or generate risks for the world economy. This definition shows that there are external factors that cause macroeconomic imbalances in each country, but these external factors are not the only sources of disturbance, there are also internal sources that disturb the macroeconomic balance.

Tansi (1982) attempted to explain the causes of budget deficits in developing countries, using the concepts of budget imbalance and fiscal imbalance scenarios. He identified five dominant scenarios:the boom in exports, the public enterprise, the inelastic tax system,terms of trade, and public spending growth.His analysis allowed us to confirm that there are external and internal determinants of the budget deficit.

This work presents only a few theoretical foundations and empirical work carried out concerning the external determinants of budget deficit.

A review of this work makes it possible to refocus the question better and to make ita thorough analysis. Also, a descriptive analysis of the variables used in this work could shed light on conceptual questions relating to the structural characteristics of our country.

The main objective of the work is to examine the effect of external sector variables that can explain the budget balance in Morocco, and to know if this effect is direct or indirect.This will lead us to formulate the question as follows: How do external variables affect the budget balance in Morocco?

To achieve this objective, we will first present a literature review of the external determinants of the budget balance.Second, a descriptive analysis of the variables used in this study will be presented. Finally, the main results of the empirical study will be presented.

\section{LITERATURE REVIEW}

According to the review of the theoretical and empirical literature, external variables can explain the budget imbalance for developing countries. These variables depend mainly on the degree of trade openness of the country studied. 


\subsection{Effect of Export Revenues}

In poorly diversified economies where almost all export revenuesdepend on the sale of one product or a small number of primary products, the export revenues factor appears to be an important determinant.

However, the effect of fluctuations in export earnings on the budget deficit is ambiguous. The improvement in the state budget balance is the result of improved export earnings which is due to the increase in the prices of exported goods (or quantities exported), but if these export earnings are intended for finance permanent public expenditure;a turnaround in the international situation leads to a fall in these public revenues and consequently a worsening of public deficits. Mansouri.B (2003) has shown, for the case of Morocco, that the contribution of the OCP has a positive effect on both total public expenditure and on capital expenditure.

The effect on capital expenditure is relatively stronger in terms of both magnitude and statistical significance. A large part of this effect is due to the fact that once capital expenditure is incurred, the realization of the investment projects that they involve should be done subsequently by resorting to other means of financing other than the contribution of the OCP itself.It is these additional expenditures that lead to the use of debt and therefore the formation of budget deficits (Mansouri.B, 2003).

\subsection{Effect of Trade Opening}

Positive and negative external shocks have asymmetric effects on public finances by creating a ratchet effect on public spending. This could be explained either by the Dutch disease hypothesis (Collier and Gunning, 1999) or by the political pressure argument (Alesina and Perotti, 1994).

The Dutch disease hypothesis is that governments do not increase public savings to respond to positive external shocks because temporary shocks are assumed to be permanent, and the duration of shocks associated with asymmetric costs of error is uncertain. In developing countries, terms of trade instability is a determining factor in a country's macroeconomic performance because terms of trade shocks tend to last longer in countries that import a large share. petroleum products, and which export a small share of non petroleum commodities with lasting price fluctuations(Cashin and Pattillo, 2000).

Developing countries face temporary commodity shocks that can lead governments to make serious budgetary policy mistakes. If the government spared all of the income from a positive external commodity shock, the Dutch disease hypothesis would no longer be relevant.

However, most shocks occur in a context where their duration cannot be easily discerned. Given the high degree of uncertainty about the persistence of price shocks, the effect of trade shocks on budget balances depends in part on the existence or not of asymmetries between the consequences of errors of optimism and pessimism (Collier and Gunning, 1999).

If the cost of errors of optimism exceeds those of pessimism, trade shocks could deteriorate budget balances. Therefore, according to the theory of Dutch syndrome, governments do not have high savings rates in response to shocks, on the one hand because temporary shocks are considered permanent, and, on the other hand, because of the uncertainty coupled with the costs of asymmetric errors.

Public spending could increase in response to a positive shock, even if the duration of the shocks is certain. Fluctuations in the tax base are often important in developing countries.

Thus, full fiscal smoothing or full consumption smoothing would imply running large budget surpluses in good times and large budget deficits in hard times. However, the ability of governments to run large budget surpluses is hampered by political pressures which are exacerbated in difficult times (Alesina and Perotti, 1994).

Indeed, suppose that a country faces a temporary positive external shock involving more temporary public revenues. If the government were to save all of the revenue from this shock, it will have to resist public spending and ministerial spending pressures.The decision of each department to shift spending in the future could be frustrated by increased other ministries spending (Collier and Gunning, 1999).

Thus, during a positive external shock, each ministry has strong incentives to increase its own spending. Talvi and Végh (2000) suggest that political pressures during positive shocks involve both decreasing the fiscal effort and increasing public spending.However, they do not take into account the asymmetries between the impact of negative and positive shocks. Under a positive shock, governments increase current and capital spending. However, in a negative shock, it would be difficult for governments to cut current spending. This implies a reduction in public investment and / or an increase in budget deficits.

Thus, the most open economies are more exposed to external shocks, which reinforces the negative relationship between terms of trade instability and budget balances. If the fluctuations in the tax base are small, expenditure pressures do not play a large role and full tax smoothing or full consumption smoothing will be taken as approximations. 
When the fluctuations in the tax base are large, political pressures become more difficult to resist and have a major impact on fiscal policy. Consequently, countries with an unstable tax base have the most volatile public spending patterns and therefore, through the ratchet effect, higher budget deficits. Also, countries that have implemented outward-looking policies also have a better capacity to cope with shocks, which means that they have greater resilience and therefore more disciplined budgets (Combes and Guillaumont, 2002).

\section{EVOLUTION OF MACROECONOMIC VARIABLES IN MOROCCO}

\subsection{Evolution of the budgetary balance}

Graph 1 below shows a worsening of the budget deficit until 1983 before improving following the implementation of the structural adjustment program. The deficit fell from 9,2\% of GDP in 1983 to 2,2\% of GDP in 1992.The period of 1993-2007 was characterized by the decline in public investment spending and the incompressibility of debt spending. The receipts recorded an increase especially those fiscal and exceptional of privatization. The deficit fell to 3,1\% of GDP on average over the period 19962003 compared to 3,3\% between 1990 and 1995.

After the 2008 global crisis, the State stepped up its efforts to control public expenditure, especially that of the wage bill, and to encourage the private sector, especially the informal sector, through one of the advantageous tax programs in order togenerate more revenue. This period is characterized by government initiatives for tax reform, and by a budget deficit that fell from $5,1 \%$ of GDP in 2013 to $4,3 \%$ in 2016.

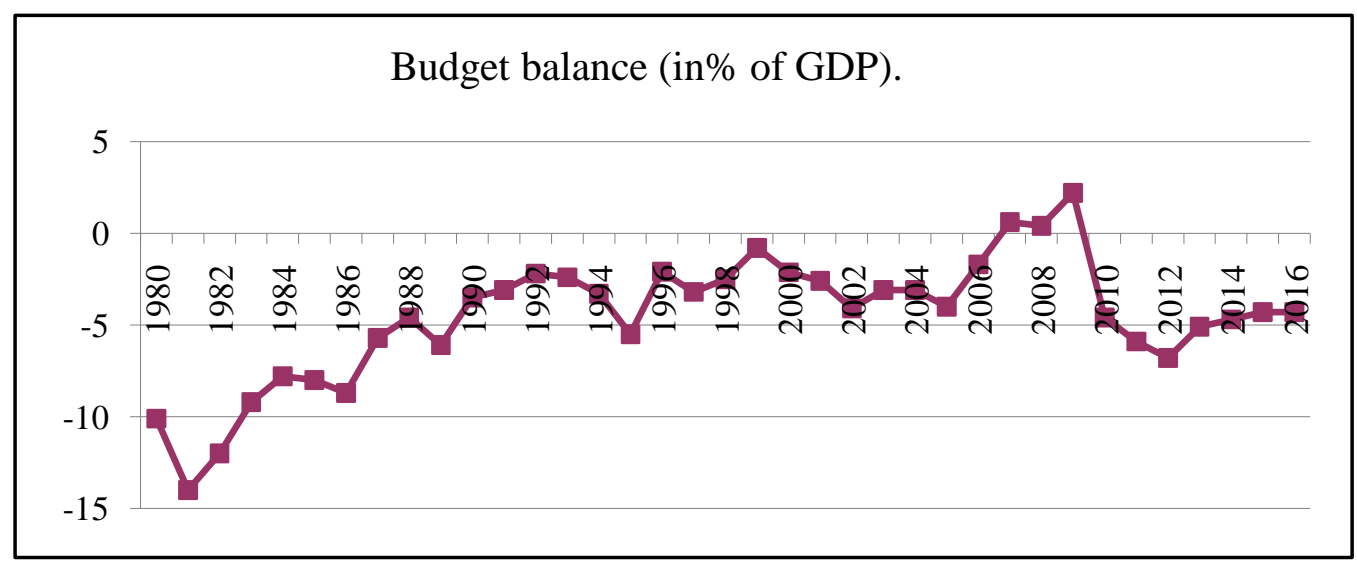

Graph 1: Evolution of the budget balance (in\% of GDP)

(Source: elaborate from statistics of the Ministry of the Economy)

\subsection{Evolution of External Variables}

\subsubsection{Degree of Trade Openness}

The degree of trade openness can be measured by several indicators, but the most widely used is the ratio of exports and imports to GDP.

It is a very useful indicator to observe the openness of an economy compared to abroad.It is most often interpreted as a measure on trade restrictions or a measure of the importance of trade to the economy.

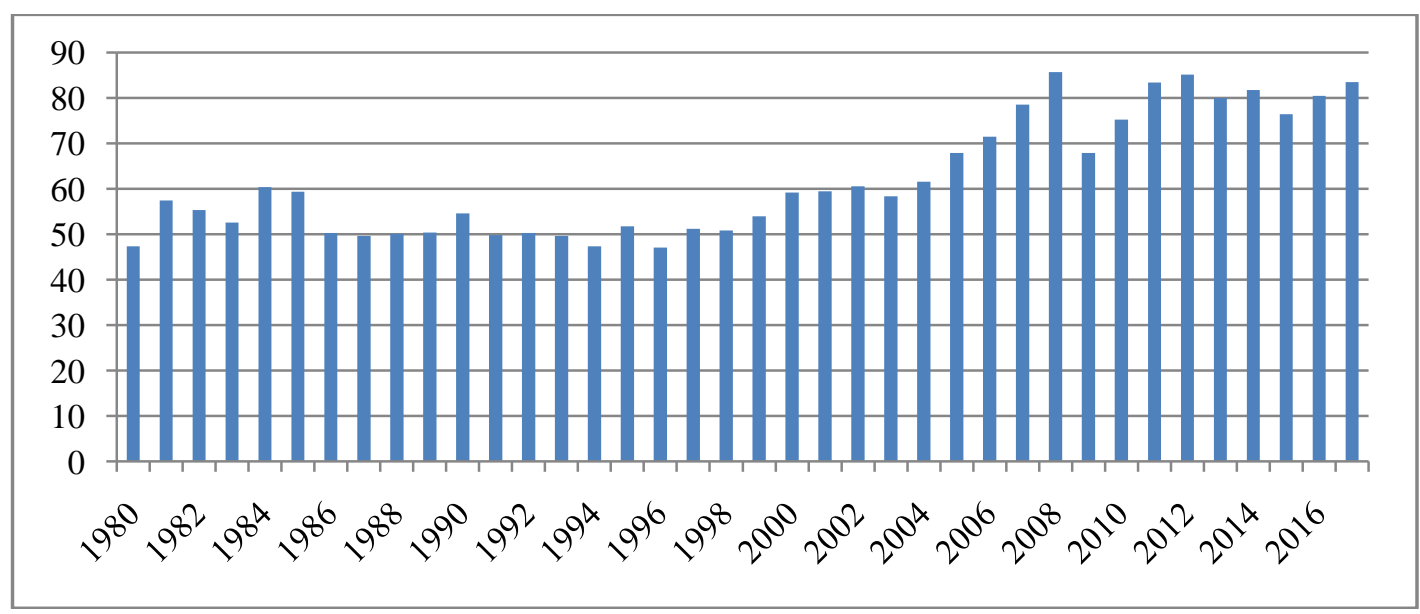

Graph 2: Evolution of the degree of openness (in\% of GDP)

(Source: elaborate using data from the World Bank) 
The degree of openness rose from $47.34 \%$ of GDP in 1980 to $83.46 \%$ of GDP in 2016. This strong increase can be explained by the procedures for the Moroccan economy liberalization, the reduction of customs tariffs, 'elimination of barriers, and simplification of procedures for foreign trade. It is also explained by the signing by Morocco of a set of free trade agreements between bilateral and regional partners.

\subsubsection{Terms of trade}

Terms of trade are important information for understanding international trade. They represent a static measure that compares the prices of exports to the prices of imports. An improvement in a country's terms of trade of $1 \%$ means that the growth in the price of exports is $1 \%$ greater than that of the price of imports. It is then that this country sells its exports more expensive (by $1 \%$ ) for a constant price of its imports, thus indicating, on the one hand the deterioration of the price competitiveness of the country and on the other hand the gain of the power of purchase of exports from this country in terms of imports.

The impact of the worsening terms of trade on the budget balance is difficult to quantify. While this deterioration may lead to a fall in some public revenues and lead to an increase in some transfer expenditures, it could also probably induce a fall in other public expenditures, such as investment expenditures, and the net effect of this on public deficits would depend on the relative intensity of the impact on public revenue and expenditure.

Monitoring the evolution of the terms of trade is an important element in the monitoring and analysis of the country's economic fluctuations, since the variation of these terms can affect the purchasing power of exports in imported products, and therefore following the trade deficit.

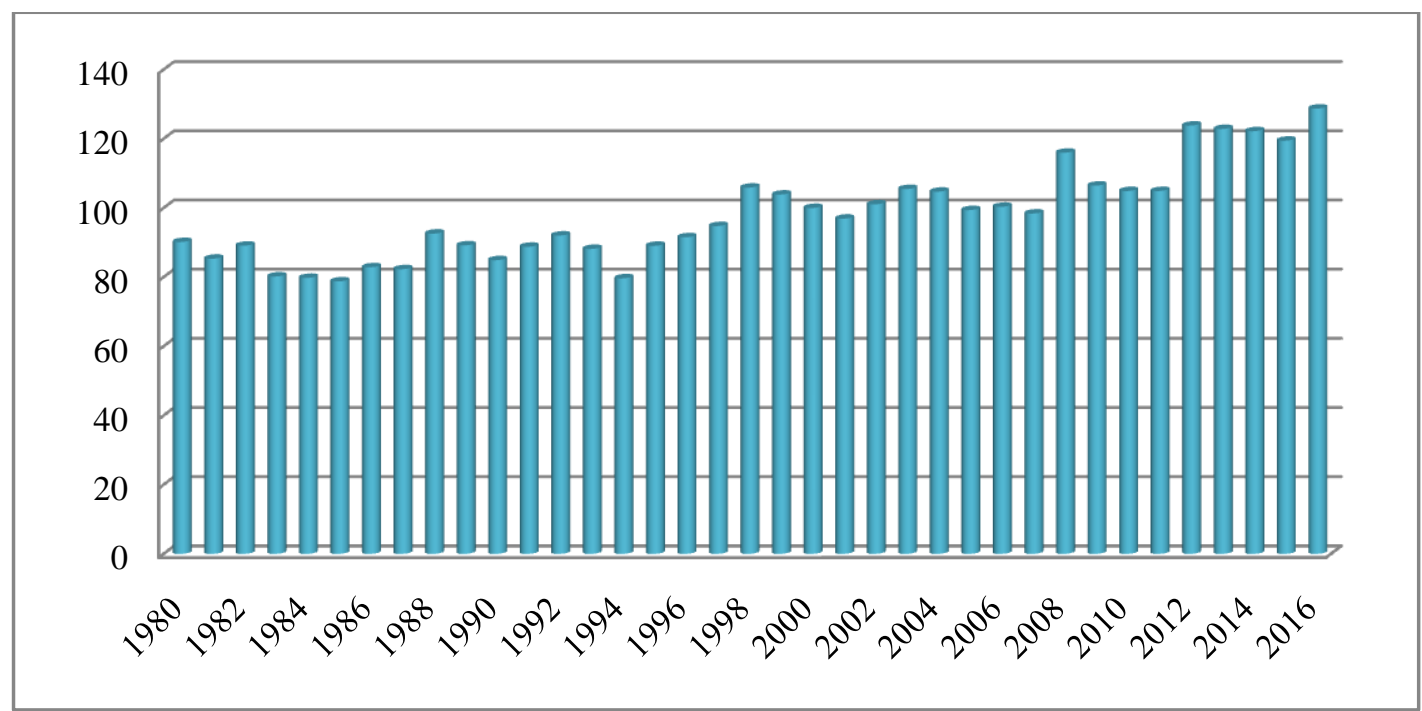

Graph 3: Evolution of the terms of trade indexbetween 1980 and 2016

(Source: elaborate using data from the World Bank)

According to graph 3, the terms of trade recorded a high value in 2016 . They went from $90.16 \%$ in 1980 to $118.77 \%$ in 2016 . This improvement represents a favorable factor for purchasing power. Moroccan exports.

\subsubsection{Oil price}

The price of oil has a direct and indirect impact on the economy and especially on the general level of prices. Its direct effect is the immediate response of domestic prices to international prices. The indirect one is the increase in the internal cost of local goods and services resulting from the increase in the price of imported oil.For importing countries such as Morocco, the drop in the price of oil alleviates their energy bill and the costs of energy subsidies.Rising disposable income and falling production costs could contribute to the growth in domestic demand. 


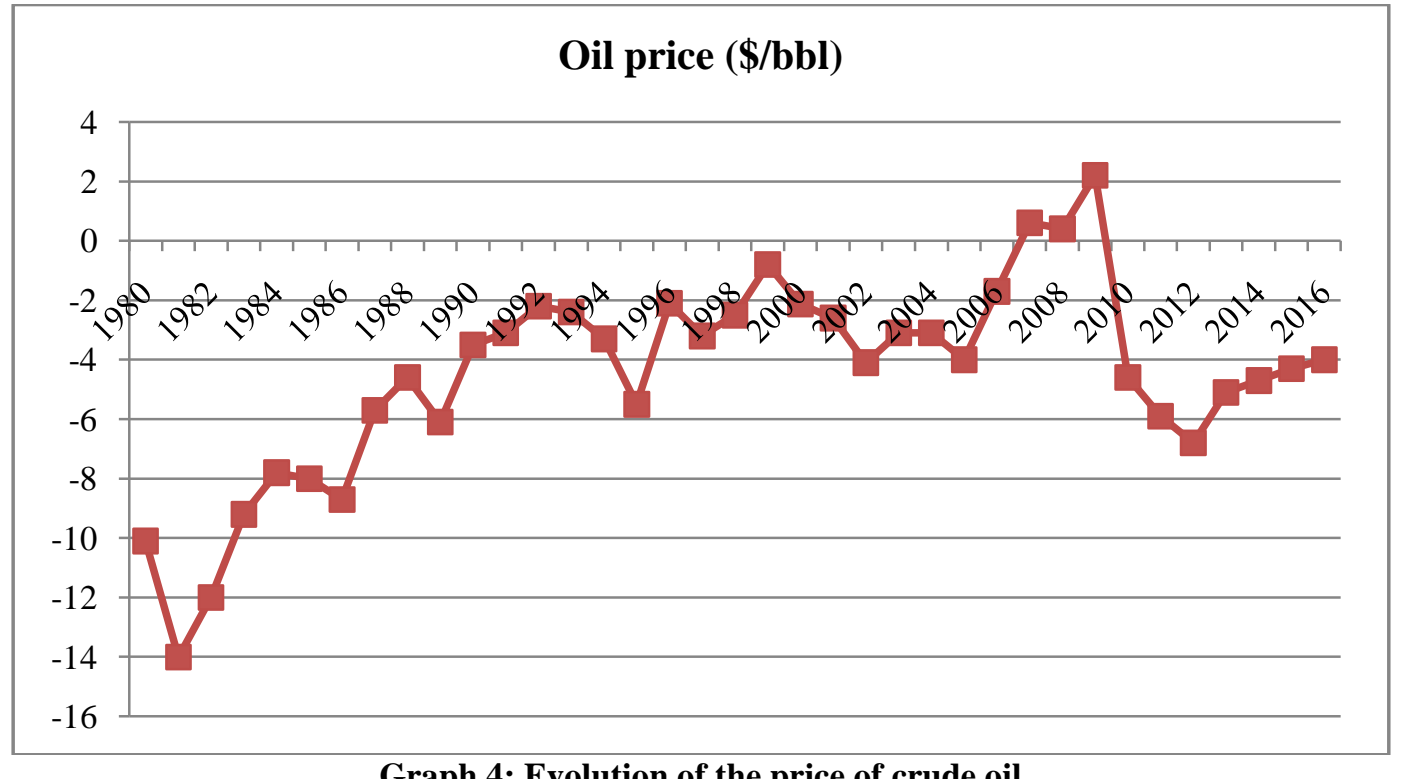

Graph 4: Evolution of the price of crude oil

(Source: elaborate from statistics of Global Economic Monito Commodities (2017))

The year 1973 marked the start of the world's first oil shock. The latter results in a reduction in production due to the increase in the price of oil. The Islamic revolution in Iran in 1979 then the war between Iran and Iraq in September 1980 caused a second oil shock due to the considerable reduction in exports from these countries.

Subsequently, a relative stability in oil prices was established between the oil counter shock of 1986 and the end of the 1990s. During this period, the main disturbances were the ephemeral peak recorded at the end of 1990, following the invasion of the Kuwait by Iraq, and the fall observed in 1998, following an error of anticipation. These first two oil shocks resulted from a disruption in supply, which is why they are said to be supply shocks.

Since the end of 2004, oil prices have shown a higher increase in nominal terms than that observed during the 1980s. Unexpectedly strong demand for oil was a major factor in the surge in oil prices. The price fell from $39,04 \$$ / barrel in December 2004 to $105,48 \$$ / barrel in 2013 to stabilize at $45,26 \$$ / barrel in 2016 .

\subsubsection{Exhange rate}

The exchange rate is one of the most important instruments of economic policy in an outward-looking country. It is considered both a means of monetary regulation and a tool par excellence for a country's external competitiveness. Since the 1980s, Morocco, like other developing countries, has had to resort to the adjustable exchange rate policy as one of the policy instruments for the recovery of its economy.

Before the 1980s, Morocco pursued an exchange rate policy which ranges from stability to depreciation at first, then from control to progressive liberalization at a second stage. On the other hand, Morocco has opted, since the beginning of the 1980s, for an active exchange rate policy aimed at remedying external imbalances.This policy led to a partial convertibility of the dirham (1993), to the creation of an exchange market open to banks (1996), toprogressive (since 1983) and accelerated liberalization (since 2005).

The graph below shows the evolution of the real effective exchange rate in Morocco for the period from 1980 to 2016. To this end, until 1990, the level of the real exchange rate remained fairly stable. Subsequently, it appreciated due, in particular, to wage and price rigidities as well as the appreciation of the euro against the dollar at the end of 2000. 




Graph 5: Evolution of the real effective exchange rate index $(2010=100)$

Source: elaborate using data from the World Bank

During the second quarter of 2001, the authorities decided to devalue the value of the dirham by around $5 \%$. This devaluation resulted in the modification of the weighting of the composition of the basket while focusing more and more on the euro to the detriment of the dollar, to better reflect the anchoring of the Moroccan dirham to the European currency.

For the period from 2001 to 2014, the price of the dirham experienced a fairly slow but very regular depreciation in real terms. Thus, the real effective exchange rate went from 107.37 in 2001 to 97,71 in 2014 , while it recorded a slight appreciation between the years 2015 and 2016. It went from 98,09 in 2015 to 100,42 in 2016.

\section{DATA AND METHODOLOGY}

\subsection{Data}

To explain the formation of the budget balance, we consider the ratio to GDP of the overall budget balance (BB) as a function:

- The real effective exchange rate (REER): is an indicator of the competitiveness of national products. Any appreciation of this rate results in an increase in demand for foreign products to the detriment of domestic products.

- The degree of trade openness (DO): measured by the total value of exports and imports of goods and services in relation to GDP. It is a very useful indicator to observe the openness of an economy compared to abroad.

- Oil price (\$ / barrel) at the end of each year (OP): The barrel of oil is a unit of measurement nowadays used to quantify a volume of crude oil or one of its derivatives.

The data in this study comes from the World Bank and Ministry of Economy and Finance indicators. They are time series (annual) that cover the period 1980-2016.

The hypothesis of this study is as follows:

- external variables could explain the budget balance directly or indirectly.

The expected signs are summarized in the following table:

Table 1: Expected effect of external variables on the budget balance

\begin{tabular}{|c|c|}
\hline Variables explicatives & ExpectedSigns \\
\hline Degree of openness (ln DO) & $? ?$ \\
\hline Oilprice (ln PP) & $? ?$ \\
\hline Real effective exchange rate (ln REER) & $(-)$ \\
\hline
\end{tabular}




\subsection{Methodology}

We use a VAR model to study the relationship between the budget balance, the price of oil, the real effective exchange rate and the degree of openness. In this model, each of the variables is a function of its own past values and those of each of the other variables (Guidi, 2009). This model treats all the variables of the model as endogenous and does not require a priori structural identification of the selection of the variables (Sims, 1980). The representation of the VAR model is as follows: ( $\mathrm{j}=$ the number of lags).

$$
\begin{aligned}
& \mathrm{BB} t=\mathrm{a} 1+\sum_{\mathrm{j}=1}^{\mathrm{p}} \mathrm{a} 11 \mathrm{j} \mathrm{BB} \mathrm{t}-\mathrm{j}+\sum_{\mathrm{j}=1}^{\mathrm{p}} \mathrm{a} 12 \mathrm{j} \mathrm{OPt}-\mathrm{j}+\sum_{\mathrm{j}=1}^{\mathrm{p}} \mathrm{a} 13 \mathrm{j} \text { RER } \mathrm{t}-\mathrm{j}+\sum_{\mathrm{j}=1}^{\mathrm{j}=1} \mathrm{a} 14 \mathrm{j} \mathrm{DO} \mathrm{t}-\mathrm{j}+\mathrm{elt} \\
& \mathrm{OP}_{\mathrm{t}}=\mathrm{a} 2+\sum_{\mathrm{j}=1}^{\mathrm{p}} \mathrm{a} 21 \mathrm{jBB} \mathrm{t}-\mathrm{j}+\sum_{\mathrm{j}=1}^{\mathrm{p}} \mathrm{a} 22 \mathrm{OP} \mathrm{O}-\mathrm{j}+\sum_{\mathrm{j}=1}^{\mathrm{p}} \mathrm{a} 23 \mathrm{j} \text { REERt }-\mathrm{j}+\sum_{\mathrm{j}=1}^{\mathrm{P}} \mathrm{a} 24 \mathrm{j} \mathrm{DO} \mathrm{t}-\mathrm{j}+\mathrm{e} 2 \mathrm{t} \\
& \text { REERt }=a_{3}+\sum_{j=1}^{p} a_{3} 1 j B B t-j+\sum_{j=1}^{p} a 32 j \text { OPt }-j+\sum_{j=1}^{p} a 33 j \text { REER } t-j+\sum_{j=1}^{P} a 34 j D O t-j+e 3 t \\
& \mathrm{DO}_{\mathrm{t}}=\mathrm{a} 4+\sum_{\mathrm{j}=1}^{\mathrm{p}} \mathrm{a} 41 \mathrm{jBB} \mathrm{t}-\mathrm{j}+\sum_{\mathrm{j}=1}^{\mathrm{p}} \mathrm{a} 42 \mathrm{j} \mathrm{OPt}-\mathrm{j}+\sum_{\mathrm{j}=1}^{\mathrm{p}} \mathrm{a} 43 \mathrm{j} \text { RERt }-\mathrm{j}+\sum_{\mathrm{j}=1}^{\mathrm{P}} \mathrm{a} 44 \mathrm{j} \mathrm{DO} \mathrm{t}-\mathrm{j}+\mathrm{e} 4 \mathrm{t}
\end{aligned}
$$

First, we test the steady state of the variables using the Augmented Dickey Fuller (ADF) test. Second, we test the cointegration of the variables using the Johansen method. Next, we proceed with the Vector Autoregression (VAR) method to estimate the relationship between the variables. From the VAR model, we will derive the impulse response function (IRF).

\section{RESULTS AND DISCUSSION}

\section{1- Stationarity test}

The analysis of the stationarity of the studied series is an essential step. Indeed, it is the stochastic nature of the series that dictates

\begin{tabular}{|c|c|c|c|c|c|}
\hline $\begin{array}{c}\text { Variable in } \\
\text { level }\end{array}$ & Lag & $\begin{array}{l}\text { Trend+I } \\
\text { I or Non }\end{array}$ & T stat & Critical value & $\begin{array}{c}\text { Conclusion: } \\
\text { stationary }\end{array}$ \\
\hline LDO & 0 & trend $+\mathrm{I}$ & $-2,250$ & $-3,540$ & No \\
\hline LOP & 0 & trend+I & $-2,001$ & $-3,540$ & No \\
\hline LREER & 1 & intercept & $-2,856$ & $-2,948$ & No \\
\hline
\end{tabular}
the typology of the appropriate modeling: if the series are stationary in level, there will be a direct use of the VAR model. The results of the stationarity test are presented in the following table:

Table 2: The results of the ADF test

Analysis of the table shows that all the variables are not stationary in level. We then proceed to the first difference stationarity test (see Table 3).

Table 3: The first difference ADF test results

\begin{tabular}{||c||c||c||c||c||c||}
\hline $\begin{array}{c}\text { Differentiated } \\
\text { variables }\end{array}$ & Lag & $\begin{array}{c}\text { Trend+I } \\
\text { I ou Non }\end{array}$ & T-stat & Critical value & Conclusion \\
\hline \hline LDO & 0 & trend+I & $-7,691$ & $-3,544$ & $\mathrm{I}(1)$ \\
\hline \hline LOP & 0 & trend+I & $-5,784$ & $-3,544$ & $\mathrm{I}(1)$ \\
\hline \hline LREER & 0 & none & $-4,173$ & $-1,195$ & $\mathrm{I}(1)$ \\
\hline
\end{tabular}

The results from the application of the ADF test (at the 5\% threshold) on the first difference series show that they are stationary. 


\section{-5.2Cointegration test}

The Johansen test makesit possible to verify the cointegration relation between the series. Therefore, if this relationship is confirmed, it is possible to argue that the series display the same long-term dynamics and that some form of relationship binds them.

Table 4: Results of the Johansencointegration test on the variables

\begin{tabular}{|c|c|c|c|c|c|}
\hline H0 & H1 & $\begin{array}{c}\text { Trace } \\
\text { Statistics }\end{array}$ & $\begin{array}{c}\text { Critical value } \\
\text { at 5\% }\end{array}$ & $\begin{array}{c}\text { Maximum } \\
\text { eigenvaluestatistic }\end{array}$ & $\begin{array}{c}\text { Critical value } \\
\text { at 5\% }\end{array}$ \\
\hline $\mathrm{r}=0$ & $\mathrm{r}>0$ & 47,21 & 25,54 & 27,58 & 27,58 \\
\hline $\mathrm{r} \leq 1$ & $\mathrm{r}>1$ & 21,66 & 13,81 & 21,13 & 21,13 \\
\hline $\mathrm{r} \leq 2$ & $\mathrm{r}>2$ & 7,85 & 7,27 & 14,26 & 14,26 \\
\hline $\mathrm{r} \leq 3$ & $\mathrm{r}>3$ & 0,58 & 3,84 & 0,58 & 3,84 \\
\hline
\end{tabular}

The statistic of the trace and the maximum eigenvaluedoes not reveal a cointegration relation between the variables of the model. Based on these results, the only way out is to estimate a first difference VAR model and analyze the impulse responses.The IRF impulse response function explains, in particular, how a shock of one of these variables would affect the value of the other variable. It also traces the effect of a single shock, on one of the innovations, on the current and future values of endogenous variables.The following figure presents the functions of the impulse responses of each variable to shocks on the other variables included in the model.

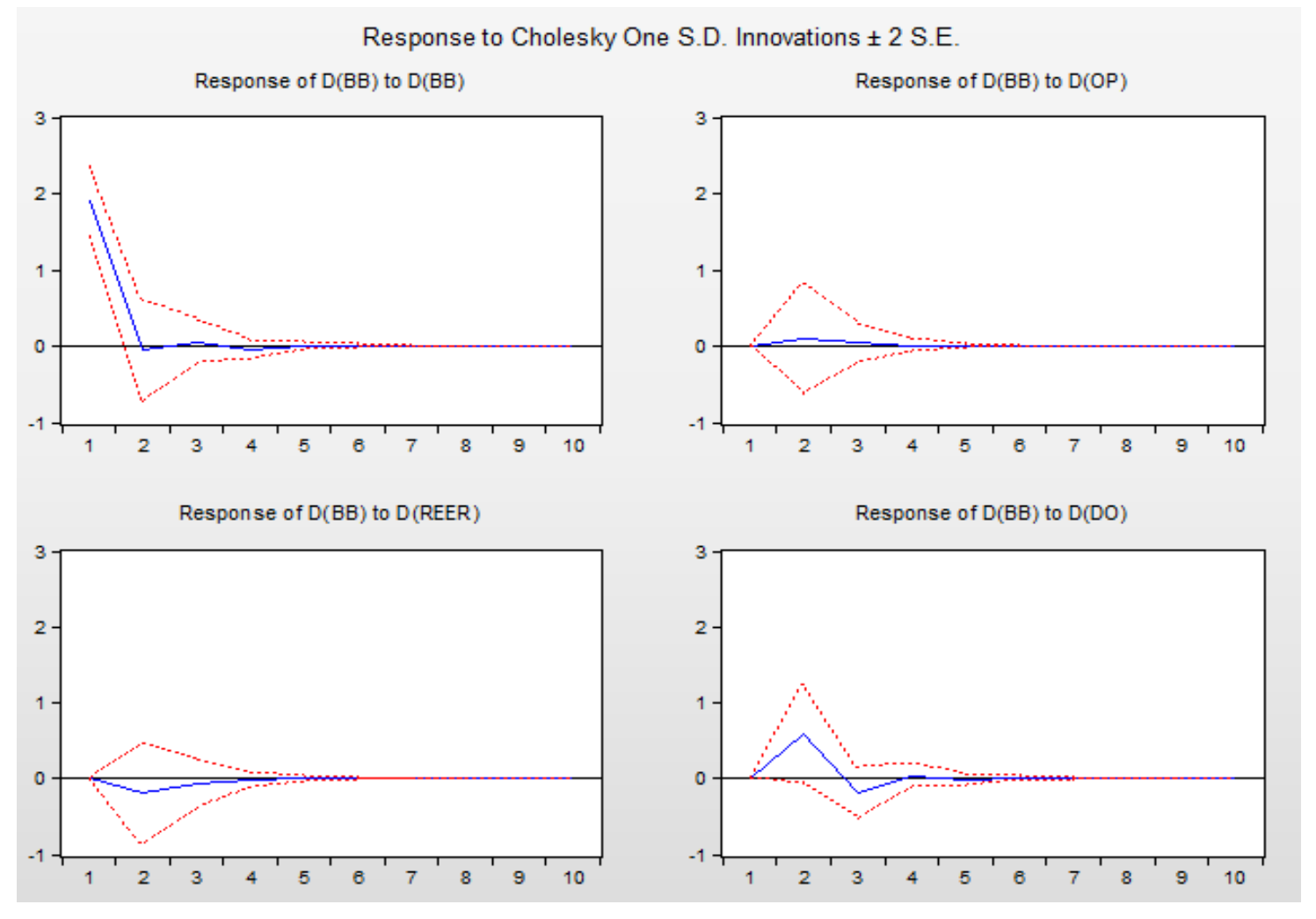

Figure 1: The functions of the impulse responses

All functions converge towards the zero value, which confirms the stability of the VAR model.

\section{- Effect of real effective exchange rate}

Analysis of impulse responses shows that a positive shock to the real effective exchange rate generates a widening budget deficit. The real effective exchange rate can indirectly affect the budget balance through the current account balance of the balance of payments.

The empirical analyzes of EL BAZ, A (2015) confirmed this indirect relationship. He concluded that any real appreciation of the 
dirham would lead to deterioration in the current balance of the balance of payments in the short and long term, causing a deterioration in the budget balance.

Since the real effective exchange rate is an indicator of the competitiveness of Moroccan exports, low export prices cannot improve the current account and thus the budget balance. Therefore, Morocco's specialization in the production of goods and services with low added value prevents the increase in export earnings, which negatively and indirectly affects the budget balance.

\section{- Effect of oil price}

A positive shock to the oil price does not have a significant influence on the fiscal balance in the short term. The price of oil has an indirect effect on the long-term fiscal balance. This effect depends on the increase in imports which would lead to a worsening of the current account deficit as a percentage of GDP. It also concerns a generation of reduced tax revenues and an increase in government spending, especially in terms of subsidies. The impact of oil prices on spending is examined in the following equation:

$\mathrm{PubE}=2,36 * \mathrm{OP}+0,27$

$(1,75) \quad(0,97)$

From the above equation, we conclude that oil prices have a positive impact on government spending which negatively affects the overall balance. Rising prices can also increase private sector production costs, reducing enterprise profits and government tax revenues.

\section{- $\quad$ Effect of the degree of trade openness}

The budget balance reacts positively to the shock of the degree of trade openness in the short and long term. This result is mainly due to the nature of the trade policy pursued by Morocco, especially the diversification policy. Hence the need to seek incomegenerating markets.

\section{CONCLUSION}

An overview of the main debates on the budget deficit has enabled us to remember that the sources of this imbalance are different. They can be linked to internal and external variables.In this work, we studied the main external factors of the budget deficit. After having briefly presented a review of theoretical and empirical literature on the external determinants of budget deficit, it is noted that the opening of countries has a significant effect on the budget balance.

The empirical results show that the external variables have direct and indirect effects on the budget balance. The price of oil has an indirect effect in the long run, and the degree of openness positively and significantly affects the budget balance in the long run. As for the real effective exchange rate, its short and long term effect is negative and relatively small in terms of magnitude. It influences the budget balance through the current account of the balance of payments.

In the light of these main results, and in order to cope with negative external shocks, it is necessary for decision-makers to adopt a policy of regulating the imports of certain goods and encouraging local products. To minimize the risks associated with free trade agreements and allow the national economy to benefit from trade openness, evaluations of these agreements, as well as their strengthening, are urgently needed.

Finally, improving the competitiveness of the national economy is more than desired. This improvement mainly involves reducing prices and improving the quality characteristics of exported goods and services.

\section{REFERENCES}

1. Alesina, Alberto, and Roberto Perotti, (1994), «The Political Economy of Budget Deficits », IMF Working Paper No. 94/85

2. Banque mondiale (2017), indicateurs de développement dans le monde

3. Bracke,T.,and al (2008), « A Framework for Assessing Global Imbalances», ECB Occasional paper series n 78.p 12

4. Cashin, Paul, and Catherine Pattillo, (2000), « Terms of Trade Shocks in Africa: Are TheyShort-Lived or Long-Lived? », IMF Working Paper $\mathrm{N}^{\circ} 00 / 72$ 
5. Collier, Paul, and Jan W. Gunning,(1999), « Trade Shocks in Developing Countries », Vol. 1 and 2 (Oxford and New York: Oxford university Press).

6. Combes, Jean-Louis, and Patrick Guillaumont, (2002), « Price Volatility,Vulnerability, and Development », Development Policy Review, Vol. 20, pp. 25-39

7. EL BAZ ,A (2015) «Interactions entre les variables externes et budgétaire au Maroc : Analyse macroéconométrique » thèse de doctorat, FSJES Marrakech

8. Guidi, F. (2009), «The economic effects of oil prices shocks on the UK manufacturing andservices sector. » de Munich Personal RePEc Archive. Availablefrom:http://www.mpra.ub.uni-muenchen.de.

9. Mansouri, B. (2003), «Soutenabilité, déterminants et implications macroéconomique desdéficits publics dans les pays en développent : cas du Maroc », Thèse de doctorat d'Etat,Université Hassan II Ain Chock. P: 95

10. Sims, A.C. (1980), « Macroeconomics and reality. », Econometrica, 48(1), 1-48.

11. Talvi, Ernesto, and Carlos A. Végh , (2000), « Tax Base Variability and Procyclical FiscalPolicy », NBER Working Paper N ${ }^{\circ}$ 7499 (Cambridge, Massachusetts: National Bureau of

12. Tansi, V.(19882) «Fiscal disequilibrium in developing countries», World development $n^{\circ} 10$

13. World Bank (2017), data statistical of Global Economic Monito Commodities. 